\title{
PENGARUH PENERAPAN GOOD CORPORATE GOVERNANCE TERHADAP FINANCIAL DISTRESS
}

\author{
Andina Nur Fathonah* \\ Universitas Widyatama, J. Cikutra No.204A, Bandung, Jawa Barat - \\ Indonesia \\ *(andina.fathonah@widyatama.ac.id)
}

\begin{abstract}
ABSTRAK
Tujuan dari penelitian ini adalah untuk mengetahui pengaruh Good Corporate Governance terhadap financial distress pada perusahaan-perusahaan sektor property, real estate dan konstruksi bangunan yang terdaftar di Bursa Efek Indonesia pada tahun 2013. Pada penelitian ini konsep good corporate governance diproksikan menggunakan indikator kepemilikan institusional, kepemilikan manajerial, komposisi dewan komisaris independen dan komite audit. Sample dipilih secara purposive dan data yang diperoleh dianalisis menggunakan regresi logistik. Hasil penelitian menunjukkan bahwa komposisi dewan komisaris independen secara signifikan berpengaruh negatif terhadap financial distress. Sementara kepemilikan institusional, kepemilikan manajerial dan komite audit, secara berturut-turut, berpengaruh negatif, positif dan positif terhadap financial distress, namun tidak signifikan.
\end{abstract}

Kata kunci: kepemilikan institusional, kepemilikan manajerial, komposisi dewan komisaris independen, komite audit, financial distress

\section{ABSTRACT}

The purpose of this study is to determine the effect of good corporate governance on financial distress in the property, real estate and construction of buildings companies listed on the Indonesia Stock Exchange in 2013. In this research, the concept of good corporate governance is proxied using indicators of institutional ownership, managerial ownership, the composition of the independent board and audit committee. Sample selected purposively and the data were analyzed using logistic regression. The results showed that the composition of the independent board significantly have negative effect on financial distress, while institutional ownership, managerial ownership and the audit committee, respectively, have negative effect, positive and positive impact on financial distress, yet insignificant.

Keywords: institutional ownership, managerial ownership, the composition of the independent board, audit committee, financial distress 


\section{PENDAHULUAN}

Kebangkrutan

dari suatu perusahaan dapat diukur dengan laporan keuangan yang diterbitkan oleh perusahaan tersebut, laporan keuangan perusahaan merupakan satu sumber informasi mengenai posisi keuangan perusahaan, kinerja serta perubahan posisi keuangan perusahaan yang sangat berguna untuk mendukung pengambilan keputusan yang tepat. Data keuangan harus dikonversi menjadi informasi yang berguna dalam pengambilan keputusan ekonomis. Model financial distress perlu untuk dikembangkan, karena dengan mengetahui kondisi financial distress perusahaan sejak dini diharapkan dapat dilakukan tindakan-tindakan untuk mengantisipasi yang mengarah kepada kebangkrutan.

Fenomena yang terjadi menjelang akhir triwulan III-2008, perekonomian dunia dihadapkan pada satu babak baru yaitu runtuhnya stabilitas ekonomi global, seiring dengan meluasnya krisis finansial ke berbagai negara. Tidak menutup kemungkinan kondisi ini bisa juga dapat dirasakan dampaknya di Indonesia salah satunya adalah industri properti. Pada tahap awal goncangan itu sudah dipicu dengan ditandai oleh naiknya BI rate. Ketika kredit konstruksi dan kredit properti yang berbunga tinggi maka tingkat pengembalian dari debitur akan mengalami gangguan. Apalagi ditambah dengan kondisi daya beli masyarakat yang menurun hingga bisa menyebabkan macetnya pembayaran kredit perumahan baik RSh maupun real estate. Maka kemungkinan krisis ekonomi di Indonesia akan terjadi mirip tahun 1997 - 1998).

Dampak yang akan menyelimuti masyarakat yang akan terus dibayang-bayangi kredit perumahan yang akan semakin berat dikarenakan kenaikan BI rate. Krisis keuangan di Amerika Serikat yang terjadi sekarang sebenarnya tidak berpengaruh langsung terhadap keseluruhan kegiatan industri properti di Tanah Air. Berbeda dengan dampak yang dirasakan akibat krisis ekonomi yang dialami Indonesia tahun 1997 - 1998. Banyak proyek properti yang berhenti seketika. Akibatnya, ketika itu terjadi gelombang pemutusan hubungan kerja (PHK). Namun demikian industri properti di Indonesia tetap terkena dampak dari krisis global ini.

Kondisi tersebut dapat mempengaruhi situasi pasar yang tidak menutup kemungkinan akan berdampak terhadap stabilitas perusahaan-perusahaan di Indonesia termasuk perusahaan yang bergerak 
di bidang Properti, Real Estate dan Konstruksi Bangunan. Fahmi (2013:68) mengatakan jika situasi dan kondisi tersebut masih berada dalam posisi kendali manajemen (management control) maka dianggap dalam posisi aman, namun apabila sebaliknya (uncontroller) maka perusahaan akan mengalami kendala dan masalah baik secara finansial maupun non finansial.

Ujiyantho (2007) dalam Widyasaputri (2012:2) menyatakan Corporate Governance merupakan salah satu elemen kunci dalam meningkatkan efisiensi ekonomis, yang meliputi serangkaian hubungan antara manajemen perusahaan, dewan komisaris, dan pemegang saham dan stakeholder lainnya. Efisiensi ekonomis dalam suatu perusahaan ini memegang peranan penting dimana hubungan antara menajemen perusahaan, dewan komisaris, dan pemegang saham ngdan stakeholder lainnya harus berjalan beriringan satu dengan yang lainnya.

Komite Nasional Kebijakan Governance (KNKG) dalam Pedoman Umum Good Corporate Governance (2006:8) menjelaskan untuk mencapai keberhasilan dalam jangka panjang, pelaksanaan GCG perlu dilandasi oleh integritas yang tinggi, sehingga diperlukan pedoman perilaku yang dapat menjadi acuan bagi organ perusahaan dan semua karyawan dalam menerapkan nilainilai (values) dan etika bisnis sehingga menjadi bagian dari budaya perusahaan. Prinsip-prinsip dasar yang harus dimiliki oleh perusahaan adalah:

1. Setiap perusahaan harus memiliki nilai-nilai perusahaan yang menggambarkan sikap moral perusahaan dalam pelaksanaan usahanya.

2. Untuk dapat merealisasikan sikap moral dalam pelaksanaan usahanya, perusahaan harus memiliki rumusan etika bisnis yang disepakati oleh organ perusahaan dan semua karyawan. Pelaksanaan etika bisnis yang berkesinambungan akan membentuk budaya perusahaan yang merupakan manifestasi dari nilai-nilai perusahaan.

3. Nilai-nilai dan rumusan etika bisnis perusahaan perlu dituangkan dan dijabarkan lebih lanjut dalam pedoman perilaku agar dapat dipahami dan diterapkan.

Good Corporate Governance pada dasarnya memiliki tujuan untuk memberikan kemajuan terhadap kinerja suatu perusahaan seperti serangkaian pola perilaku 
perusahaan yang diukur melalui kinerja, pertumbuhan, struktur pembiayaan, perlakuan terhadap para pemegang saham sehingga dapat dijadikan sebagai dasar analisis dalam mengkaji good corporate governance di suatu negara yang transparansi dan akuntabel dalam pengambilan keputusan.

Good Corporate Governance (GCG) secara definitif merupakan sistem yang mengatur dan mengendalikan perusahaan yang menciptakan nilai tambah (value added) untuk semua stakeholder (Monks, 2003) dalam Kaihatu (2006:2). Ada dua hal yang ditekankan dalam konsep ini, pertama, pentingnya hak pemegang saham untuk memperoleh informasi dengan benar dan tepat pada waktunya dan, kedua, kewajiban perusahaan untuk melakukan pengungkapan (disclosure) secara akurat, tepat waktu, transparan terhadap semua informasi kinerja perusahaan, kepemilikan, dan stakeholder.

Permasalahan yang akan dibahas dalam penelitian ini adalah sebagai berikut: 1) Seberapa besar pengaruh penerapan Good Corporate Governanceyang diproksikan dalam Kepemilikan Institusional dapat memprediksi perusahaan mengalami financial distress, 2) Seberapa besar pengaruh penerapan Good Corporate Governanceyang diproksikan dalam Kepemilikan Manajerial dapat memprediksi perusahaan mengalami financial distress, 3) Seberapa besar pengaruh penerapanGood Corporate Governanceyang diproksikan dalam Komposisi Dewan Komisaris Independen dapat memprediksi perusahaan mengalami financial distress, 4) Seberapa besar pengaruh penerapanGood Corporate Governanceyang diproksikan dalam Komite Audit dapat memprediksi perusahaan mengalami kesulitan financial distress.

Penelitian ini dilakukan dengan maksud untuk memperoleh data seberapa besar implementasi dari Good Corporate Governance (GCG) dapat memprediksi perusahaan mengalami financial distress. Berdasarkan perumusan masalah, penelitian ini mempunyai tujuan untuk mengetahui seberapa besar penerapan Good Corporate Governance yang dalam hal ini diproksikan dalam Kepemilikan Institusional, Kepemilikan Manajerial, Komposisi Dewan Komisaris Independen, dan Komite Audit mempunyai pengaruh terhadap financial distress. 
TELAAH LITERATUR DAN PERUMUSAN HIPOTESIS

\section{Teori Keagenan}

Hubungan keagenan adalah sebuah kontrak antara manajer (agent) dengan investor (principal). Konflik kepentingan antara pemilik dan agen terjadi ketika principal kesulitan untuk memastikan kesejahteraan principal, sehingga memicu biaya keagenan (agency cost) seperti halnya yang dijelaskan oleh Jansen dan Meckling (1976:5).

Menurut Eisenhard (1989) dalam Arief (2007:5), teori keagenan dilandasi oleh 3 buah asumsi yaitu:

1. Asumsi tentang sifat manusia

Asumsi tentang sifat manusia menekankan bahwa manusia memiliki sifat untuk mementingkan diri sendiri (self interest), memiliki keterbatasan rasionalitas

(bounded rationality), dan tidak menyukai resiko (risk aversion).

2. Asumsi tentang keorganisasian Asumsi keorganisasian adalah adanya konflik antar anggota organisasi, efisiensi sebagai kriteria produktivitas, dan asimetri informasi antara prinsipal dan agen.

3. Asumsi tentang informasi

Asumsi tentang informasi adalah bahwa informasi dipandang sebagai barang komoditi yang bisa diperjual belikan.

\section{Good Corporate Governance}

Istilah Corporate Governance (CG) pertama kali diperkenalkan oleh Cadbury Committee tahun 1992 dalam laporannya yang dikenal sebagai Cadbury Report (Tjager dkk.,2003). Terdapat banyak definisi tentang $C G$ yang pendefinisiannya dipengaruhi oleh teori yang melandasinya. Definisi Corporate Governance menurut FCGI (Forum for Corporate Governance in Indonesia) (2001:3) adalah sebagai berikut:

"Seperangkat peraturan yang
mengatur hubungan antara para
pemegang saham, pengurus
(pengelola), pihak kreditur,
pemerintah, karyawan serta
para pemegang kepentingan
intern dan ekstern lainnya yang
barkaitan dengan hak-hak dan
kewajiban mereka atau dengan
kata lain suatu sistem yang
mengatur dan mengendalikan
perusahaan".

Sjahputra

(2002:8)

menyimpulkan bahwa Corporate Governance adalah sistem yang mengatur, mengelola, dan mengawasi proses pengendalian usaha untuk menaikkan nilai saham, sekaligus sebagai bentuk perhatian kepada stakeholders, karyawan, kreditor, dan masyarakat sekitar. Good Corporate Governance berusaha menjaga keseimbangan di antara pencapaian 
tujuan ekonomi dan tujuan masyarakat.

\section{Kepemilikan Institusional}

Kepemilikan institusional adalah jumlah persentase hak suara yang dimiliki oleh institusi Beiner et al (2003) dalam Arief dan Pramuka (2007:10). Kepemilikan institusional memiliki kemampuan untuk mengendalikan pihak manajemen melalui proses monitoring secara efektif. Hal ini dikarenakan kepemilikan saham mewakili suatu sumber kekuasaan yang dapat digunakan untuk mendukung atau sebaliknya terhadap keberadaan manajemen, sehingga dengan kepemilikan institusional biaya agensi dapat diminimalkan. Pernyataan ini sejalan dengan Crutchly et al. (1999) dalam Widyantini (2009) yang menyatakan bahwa semakin tinggi kepemilikan institusional maka semakin kuat kontrol eksternal terhadap perusahaan dan hal ini dapat mengurangi biaya keagenan. Nilai perusahaan juga akan meningkat jika institusi mampu menjadi alat monitoring yang efektif.

Dwi dan Eka (2008:90) menjelaskan juga bahwa kepemilikan saham institusional adalah saham perusahaan yang dipegang oleh institusi lain. Kemungkinan suatu perusahaan berada pada posisi tekanan keuangan juga banyak dipengaruhi oleh struktur kepemilikan perusahaan tersebut. Struktur kepemilikan tersebut menjelaskan komitmen dari pemiliknya untuk menyelamatkan perusahaan. Dengan adanya institusional ownership, monitoring atas perusahaan akan meningkat. Hal ini diakibatkan karena institusi lain yang menanamkan modalnya pada suatu perusahaan akan memonitor lebih ketat, yang didukung oleh information channel yang lebih baik dibandingkan kepemilikan saham oleh individu. Perusahaan dengan kepemilikan institusional yang besar (lebih dari 5\%) mengindikasikan kemampuannya untuk memonitor manajemen. Semakin besar kepemilikan institusional maka semakin efisien pemanfaatan aktiva perusahaan. Dengan demikian proporsi kepemilikan institusional bertindak sebagai pencegah terhadap pemborosan yang dilakukan manajemen.

\section{Kepemilikan Manajerial}

Kepemilikan manjerial adalah persentase jumlah saham yang dimiliki manajemen dari seluruh jumlah saham perusahaan yang dikelola Gideon (2005:175). Hal ini berkaitan dengan rasa memiliki yang tinggi terhadap saham tersebut 
sehingga diharapkan dapat mengurangi financial distress atau kesulitan keuangan. Hasil penelitian yang dilakukan oleh Emrinaldi (2007) dalam Hastuti (2014:5) menunjukkan adanya hubungan antara kepemilikan manajerial yang semakin besar akan mengurangi kemungkinan terjadinya financial distress pada perusahaan tersebut. Menurutnya hal ini dapat terjadi karena semakin besar kepemilikan manajerial akan mampu menyatukan kepentingan pemegang saham dan manajer sehingga mampu mengurangi potensi terjadinya financial distress. Dalam penelitian ini kepemilikan manajerial diukur dengan persentase saham yang dimiliki oleh pihak manajemen perusahaan terhadap total jumlah saham yang beredar.

\section{Komposisi Dewan Komisaris Independen}

Komisaris independen adalah anggota dewan komisaris yang tidak terafiliasi dengan manajemen, anggota dewan komisaris lainnya dan pemegang saham pengendali, serta bebas dari hubungan bisnis atau hubungan lainnya yang dapat mempengaruhi kemampuannya untuk bertindak independen atau bertindak semata-mata demi kepentingan perusahaan Komite Nasional Kebijakan Governance
(2006:13). Peranan dan keberadaan Komisaris Independen dan Dewan Komisaris selaku supervisory board pada struktur organisasi menjadi sangat vital dalam memilah dan mengawasi setiap kebijakan yang akan diambil oleh Direksi selaku executive board. Sebagai komisaris independen, mereka memiliki fungsi dan kedudukan mewakili kepentingan pemegang saham independen. Dalam melaksanakan tugas dan kewajibannya sebagai pengawas perseroan, mereka juga harus terlibat, memeriksa memutuskan dan mengambil tindakan yang menyangkut kepatuhan, tanggung jawab hukum direksi atas setiap keputusan, informasi dan perilaku yang berhubungan dengan pengelolaan keuangan dan usaha perseroan (Dwi dan Eka, 2008:89). Proporsi dewan komisaris independen diukur dengan menggunakan indikator persentase anggota dewan komisaris yang berasal dari luar perusahaan dari seluruh ukuran anggota dewan komisaris perusahaan.Gideon (2005:176) menggunakan indikator dalam mengukur komposisi dewan komisaris adalah persentase jumlah anggota dewan yang berasal dari luar perusahaan, dari seluruh jumlah anggota dewan komisaris perusahaan. 


\section{Komite Audit}

Ikatan Komite Audit Indonesia (IKAI) mendefinisikan komite audit sebagai suatu komite yang bekerja secara profesional dan independen yang dibentuk oleh dewan komisaris, dengan demikian tugasnya adalah membantu dan memperkuat fungsi dewan komisaris dalam menjalankan fungsi pengawasan atas proses pelaporan keuangan, manajemen risiko, pelaksanaan audit, dan implementasi dari corporate governance di perusahaanperusahaan. Collier dan Gregory dalam Harahap (2001) menjelaskan bahwa komite audit memberikan manfaat bagi peningkatan sistem pengawasan dan juga pada GCG.

Wolnizer dalam Indriani dan Nurkholis (2002) mengungkapkan bahwa fungsi komite audit secara spesifik dapat diidentifikasikan ke dalam tiga aspek yang saling berkaitan, yaitu berhubungan dengan akuntansi dan pelaporan keuangan, auditor dan pengauditan, serta organisasi perusahaan (Dwi dan Eka, 2008:87). Bapepam melalui Surat Edaran No. 03/PM/2000 yang ditujukan kepada setiap direksi emiten dan perusahaan publik mewajibkan dibentuknya komite audit. Pengaturan mengenai jumlah komite audit bagi emiten dan perusahaan publik diatur dalam peraturan Bapepam-LK No. IX.I.5 tentang Pembentukan Pedoman Pelaksanaan Kerja Komite Audit. Dalam peraturan tersebut emiten dan perusahaan publik diwajibkan membentuk komite audit yang berjumlah sekurang-kurangnya tiga orang dimana salah satunya merupakan komisaris independen perusahaan dan bertindak sebagai ketua komite audit (Widyati, 2013:238). Pada penelitian ini, komite audit diukur dengan kompetensi komite audit yaitu jumlah anggota komite audit dengan latar belakang pendidikan dan pengalaman di bidang akuntansi dan keuangan terhadap keseluruhan jumlah anggota komite audit Atmini dan Prihatiningtias (2008) dalam Ginting (2012:53).

\section{Financial Distress}

Plat dan Plat (2006:142) mendefinisikan financial distress sebagai tahap penurunan kondisi keuangan yang terjadi sebelum terjadinya kebangkrutan ataupun likuidasi. Penelitian-penelitian yang berkaitan dengan kondisi financial distress perusahaan pada umumnya menggunakan rasio keuangan perusahaan. Penelitian tentang kondisi financial distress telah dilakukan oleh beberapa peneliti diantaranya oleh Luciana dan Kristijadi (2003) yang menggunakan 
rasio-rasio keuangan yang digunakan oleh Platt dan Platt(2002). Rasio keuangan yang digunakan oleh Platt dan Platt (2002) adalah rasio keuangan yang berasal dari informasi di dalam Neraca dan Laporan Rugi Laba.

\section{Memprediksi Financial Distress}

Gordon L.V. Springate (1978) melakukan penelitian untuk menemukan suatu model yang dapat digunakan dalam memprediksi adanya potensi (indikasi) kebangkrutan. Springate (1978) menggunakan 19 rasio-rasio keuangan populer yang bisa dipakai untuk memprediksi financial distress. Sampel yang digunakan Springate berjumlah 40 perusahaan manufaktur yang berlokasi di Kanada, yaitu 20 perusahaan yang mengalami kesulitan keuangan dan 20 yang dalam keadaan sehat. Springate akhirnya menemukan 4 rasio yang dapat digunakan dalam memprediksi adanya potensi (indikasi) kebangkrutan perusahaan. Berikut adalah rumus Springate SScore (Citrawati dan Gede, 2014:385):

$$
S=1,03 A+3,07 B+0,66 C+0,4 D
$$

Dimana:

$\mathrm{A}=$ Working Capital to Total Assets

$\mathrm{B}=$ Earnings after Interest and Taxes to Total Assets

$\mathrm{C}=$ Earnings before Interest and Taxes to Current Liabilities

$\mathrm{D}=$ Total Sales to Total Assets

S-Score dihasilkan dari perhitungan angka-angka keempat rasio yang didapatkan dari laporan keuangan dengan cara menjumlahkan angka-angka yang didapatkan dari perkalian rasio dengan koefisien yang diturunkan dari rumus Springate. Perhitungan tersebut didasarkan pada hasil penelitian yang dilakukan Springate untuk perusahaan yang sehat dan yang tidak sehat menunjukkan nilai tertentu. Kriteria/titik cut-off yang digunakan untuk memprediksi kebangkrutan perusahaan yaitu sebagai berikut:

Tabel 1. Kriteria Titik Cut-off Model S-Score

\begin{tabular}{lc}
\hline \multicolumn{1}{c}{ Kriteria } & Nilai S \\
\hline Sehat & $>0,862$ \\
Tidak Sehat & $<0,862$ \\
\hline
\end{tabular}

Sumber: Citrawati dan Gede (2014:385) 
Fathonah - Pengaruh Penerapan Good Corporate Governance ...

Kerangka Pemikiran dan Hipotesis Penelitian

Isu Good Corporate Governance muncul karena terjadi pemisahan antara kepemilikan dengan pengendalian perusahaan, atau seringkali dikenal dengan istilah masalah keagenan. Permasalahan keagenan dalam hubungannya antara pemilik perusahaan dengan manajer adalah bagaimana sulitnya pemilik dalam memastikan bahwa dana yang ditanamkan tidak diambil alih atau diinvestasikan pada proyek yang tidak menguntungkan sehingga tidak mendatangkan return. Good Corporate Governance diperlukan untuk mengurangi masalah keagenan antara pemilik dan manajer serta mengurangi terjadinya asimetri informasi dan financial distress.

Corporate Governance biasanya mengacu kepada sekumpulan mekanisme yang mempengaruhi keputusan yang akan diambil oleh manajer ketika ada pemisahan antara kepemilikan dan pengendalian, beberapa pengendalian ini terletak pada fungsi dari dewan direksi, pemegang saham institusional, dan pengendalian dari mekanisme pasar Latcker (2005) dalam Wardhani (2006:3).

Penelitian ini merupakan replika dari penelitian terdahulu yaitu Ellen dan Juniarti (2013:11) yang berjudul
Penerapan Good Corporate Governance, Dampaknya Terhadap Prediksi Financial Distress pada Sektor Aneka Industri dan Barang Konsumsi. Penelitiannya menunjukkan model yang di digunakan tidak signifikan terhadap financial distress. Jika dilihat dari metode yang dipakai menggunakan model yang dibagi menjadi tiga model yaitu tahun 2008, 2009 dan 2010 dan yang paling mendekati adalah model 2 yaitu tahun 2009 untuk memprediksi financial distress. Selanjutnya penelitian yang akan diteliti adalah studi pada perusahaan property, real estate dan konstruksi bangunan yang terdaftar di Bursa Efek Indonesia pada tahun 2008 2012.

Variabel independen yang akan digunakan dalam penelitian ini adalah Good Corporate Governance dan rasio keuangan. Proksi Good Corporate Governance menggunakan Kepemilikan Institusional, Kepemilikan Manajerial, Komposisi Dewan Komisaris Independen, dan Komite Audit. Wardhani (2006:4) merupakan salah satu peneliti sebelumnya dengan judul "Mekanisme Corporate Governance dalam Perusahaan yang Mengalami Permasalahan Keuangan (Financially Distressed Firm)". Hasil penelitiannya menunjukkan bahwa ukuran direksi 
berhubungan positif dengan kemungkinan suatu perusahaan akan mengalami tekanan keuangan, variabel komisaris tidak signifikan dalam penelitiannya, serta tingkat turn over dari direksi mempengaruhi kemungkinan perusahaan mengalami tekanan keuangan secara signifikan.

Selanjutnya dirumuskan hipotesis penelitian sebagai berikut: $\mathrm{H}_{1}$ : Kepemilikan Institusional berpengaruh terhadap financial distress.

$\mathrm{H}_{2}$ : Kepemilikan Manajerial berpengaruh terhadap financial distress.

$\mathrm{H}_{3}$ : Komposisi Dewan Komisaris Independen berpengaruh terhadap financial distress.

$\mathrm{H}_{4}$ : Komite Audit berpengaruh terhadap financial distress.

\section{METODE}

Metode penelitian yang digunakan dalam penelitian ini adalah metode asosiatif dengan hubungan kausal. Metode asosiatif adalah penelitian yang bersifat menanyakan hubungan antara dua variabel atau lebih, sedangkan hubungan kausal adalah hubungan yang bersifat sebab akibat (Sugiyono, 2012:55-56).

Populasi dalam penelitian ini adalah perusahaan yang bergerak dalam industri perusahaan Property,
Real Estate dan Konstruksi Bangunan yang terdaftar di Bursa Efek Indonesia pada tahun 2013. Sampel adalah sebagian jumlah dan karaktersistik yang dimiliki populasi tersebut (Sugiyono, 2012:389). Teknik pengambilan sampel dilakukan secara purposive sampling dengan tujuan untuk mendapatkan sampel yang representatif sesuai dengan kriteria yang ditetukan. Adapun kriteria yang digunakan untuk memilih sampel yaitu:

1. Property, Real Estate dan Konstruksi Bangunan yang terdaftar di Bursa Efek Indonesia pada tahun 2013.

2. Perusahaan mempublikasikan laporan keuangan tahunan untuk tahun 2013 yang dinyatakan dalam rupiah $(\mathrm{Rp})$

3. Data tersedia lengkap (data secara keseluruhan tersedia pada publikasi periode 2013), baik data mengenai Good Coorporate Governance (GCG) perusahaandan data yang diperlukan untuk mendeteksi financial distress.

\section{HASIL DAN PEMBAHASAN}

Pada Tabel 2 dapat dilihat nilai statistik uji wald untuk variabel kepemilikan institusional adalah sebesar 0,471 dengan nilai signifikansi sebesar 0,493. Karena 
nilai statistik uji wald untuk variabel kepemilikan institusional $(0,471)$ lebih kecil dari nilai Chi-square tabel $(3,841)$ dan $\operatorname{sig}(0,493)>\alpha$ dengan tingkat kekeliruan 5\% diputuskan menerima Ho dan menolak $\mathrm{Ha}$ sehingga dapat disimpulkan bahwa kepemilikan institusional tidak memiliki pengaruh dalam memprediksi financial distress pada perusahaan property, real estate dan konstruksi bangunan di Bursa Efek Indonesia pada periode tahun 2013.

Indikator

Kepemilikan

Institusional pada penelitian ini tidak memiliki pengaruh signifikan dalam memprediksi financial distress pada perusahaan property, real estate dan konstruksi bangunan di Bursa Efek Indonesia pada periode tahun 2013. Hal ini sejalan dengan penelitiannya Bodroastuti (2009:11) yang memiliki hasil penelitian bahwa kepemilikan institusional ternyata tidak signifikan. La Porta, Lopez-de-Silanes dan Shleifer (1998), Claessens, Djankov dan Lang (2000) serta Faccio dan Lang (2002), telah menemukan bukti bahwa lebih dari $60 \%$ dari perseroan terbuka di seluruh dunia dimiliki oleh satu pemilik terkuat (pemegang saham terbesar) kecuali di Amerika, Inggris, dan Jepang. Tsun dan Yin (2004) menyatakan lebih lanjut bahwa kepemilikan yang terpusat dapat menimbulkan kurangnya transparansi dalam penggunaan dana pada perusahaan serta keseimbangan yang tepat antara kepentingankepentingan yang ada, misalnya antara pemegang saham dengan pengelolaan manajemen perusahaan dan antara pemegang saham pengendali (controlling shareholder) dengan pemegang saham minoritas.

Tabel 2. Hasil Analisis Regresi Logistik

\begin{tabular}{lrrrrrr}
\hline & \multicolumn{1}{c}{ B } & S.E. & Wald & df. & Sig. Exp(B) \\
\hline Kepemilikan Institusional & $-1,283$ & 1,870 & 0,471 & 1 & 0,493 & 0,277 \\
Kepemilikan Manajerial & 4,374 & 5,550 & 0,621 & 1 & 0,431 & 79,326 \\
Komposisi Dewan Komisaris Independen & $-8,115$ & 4,076 & 3,963 & 1 & 0,047 & 0,000 \\
Komite Audit & 3,126 & 3,076 & 1,003 & 1 & 0,310 & 22,785 \\
Constant & 3,783 & 3,009 & 1,581 & 1 & 0,209 & 49,963 \\
\hline
\end{tabular}

Sumber: Output SPSS

Perusahaan publik yang ada di Indonesia kepemilikannya cenderung terpusat dan tidak menyebar secara merata (Gunarsih, 2003), sehingga perusahaan dengan struktur kepemilikan yang tidak menyebar secara merata menyebabkan pengendalian pemegang saham terhadap manajemen cenderung lemah. Dengan demikian pemegang 
saham tidak mempunyai kemampuan yang cukup untuk mengendalikan manajemen sehingga manajemen mempunyai kemungkinan untuk mengambil keputusan yang menguntungkan dirinya sendiri.

Sejalan dengan teori keagenan yang dilandasi salah satunya adalah asumsi tentang sifat manusia yang mementingkan diri sendiri (self interest). Terlihat berdasarkan data kepemilikan institusional pada property, real estate dan konstruksi bangunan selama tahun 2010-2013 banyak terdapat saham yang tidak menyebar dan terdapat saham mayoritas bahkan tidak sedikit pula saham yang dimiliki oleh pihak asing diatas $5 \%$, sehingga dapat mempengaruhi pengendalian dalam perusahaan serta hasil penelitian. Sama halnya penelitian yang dilakukan oleh Widyasaputri (2012) yang menolak $\mathrm{H}_{3}$ atau tidak adanya pengaruh Kepemilikan Institusional terhadap kondisi Financial Distress.

Menurut Widyasaputri (2012:6) menjelaskan bahwa berapapun besarnya persentase kepemilikan institusional dapat membuktikan adanya kemungkinan kondisi financial distress. Tidak dapat dipungkiri bahwa perusahaan dapat mengalami financial distress jika para institusi perusahaan kurang memiliki kemampuan dalam mengontrol kinerja manajer.

Hal lain diungkapkan oleh Ellen dan Juniarti (2013:10) dalam penelitiannya menjelaskan terdapat indikasi dikarenakan GCG dalam suatu perusahaan hanya sebuah formalitas yang tidak ditunjang dengan kinerja yang efisien.

Pengujian hipotesis kedua menunjukkan hasil bahwa variabel komisaris independen memiliki koefisien positif sebesar 2,609 dengan tingkat signifikansi sebesar 0,431 > a $=0,05$, yang memiliki arti bahwa komisaris independen tidak berpengaruh signifikan pada financial distress. Komisaris independen sangat dibutuhkan sikap indepedensinya dalam menjalankan tugasnya, namun terkadang seorang komisaris independen memiliki sikap independensi yang kurang, yang dapat mengakibatkan lemahnya pengawasan terhadap kinerja manajemen perusahaan, sehingga tidak akan memiliki pengaruh terhadap terjadinya financial distress. Hal ini sejalan dengan penelitiannya Putri dan Merkusiwati (2016:102).

Nilai statistik uji wald yang terdapat pada Tabel 2 untuk variabel komisaris independen adalah sebesar 3,963 dengan nilai signifikansi sebesar 0,047. Karena nilai statistik uji wald untuk variabel komisaris 
independen $(3,963)$ lebih besar dari nilai Chi-square tabel $(3,841)$ dan sig $(0,047)<\alpha$ dengan tingkat kekeliruan $5 \%$ diputuskan menolak Ho dan menerima $\mathrm{Ha}$ sehingga dapat disimpulkan bahwa komisaris independen memiliki pengaruh dalam memprediksi financial distresspada perusahaan property, real estate dan konstruksi bangunan di Bursa Efek Indonesia pada periode tahun 2013.

Koefisien komisaris independen bertanda negatif menunjukkan bahwa ada kecenderungan perusahaan dengan proporsi komisaris independen lebih banyak tidak mengalami financial distress. Komposisi Dewan Komisaris Independen dalam penelitian ini memiliki pengaruh signifikan dalam memprediksi financial distress pada perusahaan property, real estate dankonstruksi bangunan di Bursa Efek Indonesia selama periode tahun 2010-2013. Komisaris independen merupakan anggota dewan komisaris yang tidak terafiliasi dengan manajemen, anggota dewan komisaris lainnya dan pemegang saham pengendali, serta bebas dari hubungan bisnis atau hubungan lainnya yang dapat mempengaruhi kemampuannya untuk bertindak independen atau bertindak sematamata demi kepentingan perusahaan
Komite Nasional Kebijakan Governance (2006:13).

Peranan dan keberadaan Komisaris Independen dan Dewan Komisaris selaku supervisory board pada struktur organisasi menjadi sangat vital dalam memilah dan mengawasi setiap kebijakan yang akan diambil oleh Direksi selaku executive board. Sebagai komisaris independen, mereka memiliki fungsi dan kedudukan mewakili kepentingan pemegang saham independen. Dalam melaksanakan tugas dan kewajibannya sebagai pengawas perseroan, mereka juga harus terlibat, memeriksa memutuskan dan mengambil tindakan yang menyangkut kepatuhan, tanggung jawab hukum direksi atas setiap keputusan, informasi dan perilaku yang berhubungan dengan pengelolaan keuangan dan usaha perseroan (Dwi dan Eka, 2008:89). Proporsi dewan komisaris independen diukur dengan menggunakan indikator persentase anggota dewan komisaris yang berasal dari luar perusahaan dari seluruh ukuran anggota dewan komisaris perusahaan sehingga dapat dijadikan prediksi financial distress.

Koefisien komite audit memiliki koefisien positif sebesar $0,310>\alpha$ dengan tingkat kekeliruan 5\% sehingga menunjukkan tidak 
memiliki pengaruh signifikan dalam

suatu memprediksi financial distress pada perusahaan mengalami financial perusahaan property, real estate dan konstruksi bangunan di Bursa Efek Indonesia pada periode tahun 2013.

Hasil penelitian ini sejalan dengan Ellen dan Juniarti (2013:11) yang menggunakan GCG score dalam penelitiannya yang didalamnya menggunakan komite audit yang hasilnya secara konsisten tidak

distress. Hal ini mungkin
dikarenakan GCG dalam suatu perusahaan hanya sebuah formalitas yang tidak ditunjang dengan kinerja yang efisien.

Berdasarkan hasil hasil pengujian statistik secara parsial diatas dapat disimpulkan pada tabel berikut ini:

Tabel 3. Hasil Pengujian secara Parsial (Uji Wald)

\begin{tabular}{lrrrrrrl}
\hline No. & Model & $\begin{array}{c}\text { Uji } \\
\text { Wald }\end{array}$ & $\begin{array}{c}\text { Chi- } \\
\text { square } \\
\text { tabel }\end{array}$ & Sig. & a & Keputusan & \multicolumn{1}{c}{ Ket. } \\
\hline 1. & INST $\rightarrow$ FD & 0,471 & 3,841 & 0,493 & 0,05 & Ho diterima & Tidak \\
2. & MAN $\rightarrow$ FD & 0,621 & 3,841 & 0,431 & 0,05 & Ho diterima & $\begin{array}{l}\text { Signifikan } \\
\text { Tidak } \\
\text { Signifikan }\end{array}$ \\
3. & KDKI $\rightarrow$ FD & 3.963 & 3,841 & 0,047 & 0,05 & Ho ditolak & $\begin{array}{l}\text { Signifikan } \\
\text { 4. }\end{array}$ \\
KA $\rightarrow$ FD & 1.033 & 3,841 & 0,310 & 0,05 & Ho diterima & $\begin{array}{l}\text { Tidak } \\
\text { Signifikan }\end{array}$ \\
\hline
\end{tabular}

Sumber: Output SPSS

\section{Ketepatan Hasil Prediksi}

Ketepatan prediksi dari hasil estimasi model logit dengan menggunakan keempat variabel independen/prediktor ditunjukkan pada tabel 4 berikut:

Tabel 4. Ketepatan Keempat Variabel Independen Dalam Memprediksi Financial

Distress

Classification Table*

\begin{tabular}{cclccc}
\hline & & \multicolumn{2}{c}{ Predicted } & \\
& & & \multicolumn{2}{c}{ Financial Distress } & Percentage \\
& & Non-Distress & Distress & Correct \\
\hline Step 1 & Financial & Non-Distress & 10 & 4 & 71,4 \\
& Distress & Distress & 4 & 10 & 71,4 \\
& Overall Percentage & & & 71,4 \\
\hline
\end{tabular}

Pada tabel 4 dapat dilihat bahwa dari sebanyak 14 sampel yang diidentifikasi tidak mengalami financial distress, sebanyak 10 sampel diantaranya diprediksi tidak mengalami financial distress 
(ketepatan prediksi 71,4\%). Sama halnya untuk financial distress terdapat 14 sampel, sebanyak 10 sampel diantaraya diprediksi mengalami financial distress (ketepatan prediksi 71,4\%). Secara keseluruhan ketepatan prediksi kedelapan variabel independen/ prediktor (kepemilikan institusional, kepemilikan manajerial, komisaris independen, dan komite audit) dalam memprediksi financial distress sebesar $71,4 \%$.

\section{KESIMPULAN, IMPLIKASI DAN KETERBATASAN PENELITIAN}

Berdasarkan hasil penelitian dan pembahasan yang telah dijelaskan, maka penulis dapat menarik kesimpulan sebagai berikut: 1) Good Corporate Governance yang diukur oleh kepemilikan institusional dan komposisi komisaris dewan independen memiliki koefisien negatif yang artinya berpengaruh negatif dalam memprediksi financial distress, sedangkan kepemilikan manajerial dan komite audit memiliki koefisien yang positif yang artinya berpengaruh positif dalam memprediksi financial distress. Hal ini menunjukkan bahwa semakin besar kepemilikan institusional dan komposisi komisaris dewan independen cenderungtidak mengalami financial distress, sedangkan untuk kepemilikan manajerial dan komite audit bahwa semakin banyak di dalam suatu perusahaan belum tentu efisien dan efektif dalam menekan atau tehindar dari terjadinya financial distress, 2) Keempat variabel independen/ prediktor yaitu kepemilikan institusional, kepemilikan manajerial, komposisi dewan komisaris independen, dan komite audit, secara bersama-sama berpengaruh dalam memprediksi financial distresspada perusahaan property, real estate dankonstruksi bangunan di Bursa Efek Indonesia pada periode tahun 2013.

Setelah melihat hasil penelitian dan mengambil kesimpulan, maka berikut ini saran yang dapat dijadikan bahan masukan atau bahan pertimbangan beberapa pihak untuk penelitian di masa yang akan datang, antara lain sebagai berikut: 1) Untuk Operasional yaitu bagi perusahaan analisis ini merupakan salah satu alat yang dapat membantu dalam pengambilan keputusan dan mengetahui financial distress sejak dini. Perusahaan sebaiknya menganalisis dengan menggunakan strategi dan keputusan yang baik untuk kelangsungan perusahaan (going concern) karena Corporate Governance yang baik merupakan langkah yang penting dalam membangun kepercayaan (market 
confidence) dan mendorong arus investasi internasional yang lebih stabil, dan bersifat jangka panjang salah satunya dengan meningkatkan kualitas Sumber Daya Manusia (SDM) sesuai dengan kemampuan dan kriteria yang telah ditentukan oleh perusahaan, 2) Untuk Akademisi yaitu bagi peneliti selanjutnya yang tertarik untuk meneliti mengenai financial distress dapat menggunakan model lainnya seperti Model Zmijewski, Model Grover, Model Ohlson, Model Zavgren, Model Chesser dll. Periode yang diteliti bisa lebih panjang dan sebaiknya menggunakan data primer agar lebih mengetahui pengaruh good corporate governance dan rasio keuangan terhadap financial distress secara lebih baik serta mendapatkan data yang lebih lengkap untuk diteliti. Peneliti selanjutnya dapat menambahkan faktor yang dilihat dari perspektif keuangan maupun non keuangan lainnya yang mempengaruhi terjadinya financial distress.

\section{REFERENSI}

Arief, M. 2005. Asimetri Informasi dan Manajemen Laba: Suatu Tinjauan Dalam Hubungan Keagenan.

Arief, M dan Bambang Agus Pramuka. 2007. Mekanisme Corporate Governance, Manajemen Laba Dan Kinerja Keuangan.
Simposium Nasional Akuntansi $\mathrm{X}$. Makassar.

Boediono, Gideon SB. 2005. Kualitas Laba: Studi Pengaruh Mekanisme Corporate Governance dan Dampak Manajemen Laba Dengan Menggunakan Analisis Jalur. Simposium Nasional Akuntansi VIII. Solo.

Citrawati, Etta Yuliastary dan Made Gede Wirakusuma. 2014. Analisis Financial Distress dengan Metode $Z$ Score Altman, Springate dan Zmijewski. EJurnal Akuntansi Universitas Udayana 6.3 (2014): 379-389 ISSN: 2302-8556.

Fahmi, Irham. 2013. Manajemen Risiko, Teori, Kasus dan Solusi. Bandung: CV. Alfabeta

Forum for Corporate Governance in Indonesia (FCGI). 2001. Corporate Governance. Seri Tata Kelola Perusahaan (Corporate Governance) Jilid I (Edisi ke-3). Jakarta: Citra Graha.

Ginting, Yoremia Lestari BR. 2012. Pengaruh Mekanisme Corporate Governance Terhadap Manajemen Laba Serta Implikasinya Terhadap Pengungkapan CSR. Tesis. Tidak Dipublikasikan. Bandung: Universitas Padjajaran.

Hastuti, Indra. 2014. Analisis Pengaruh Struktur Kepemilikan dan Karakteristik Perusahaan Terhadap Kemungkinan Kesulitan Keuangan. Artikel Publikasi. Surakarta: Universitas Muhammadiyah.

Jensen, C, Michael and William $\mathrm{H}$. Mecling. 1976. Theory of The Firm: Managerial Behavior, Agency Cost and Ownership Structure. Journal of Financial Economics, October, 1976, V. 3, 
No. 4, pp 305 - 360. Harvard Business School and University of Rochester.

Juniarti, dan Ellen. 2013. Penerapan Good Corporate Governance, Dampaknya Terhadap Financial Distress Pada Sektor Aneka Industri dan Barang Konsumsi. Business Accounting Riview, Vol. 1, No. 2, 2013. Akuntansi Bisnis Universitas Kristen Petra.

Kaihatu, Thomas. S. 2006. Good Corporate Governance dan Penerapannya di Indonesia. Jurnal Manajemen dan Kewirausahaan Vol.8, No.1. Universita Kristen Petra.

Komite Nasional Kebijakan Governace. 2006. Pedoman Umum Good Corporate Governance Indonesia.

Platt, Harlan D dan Marjorie B. Platt. Understanding Differences Between Financial Distress and Bankruptcy. 2006. Review of Applied Economics, Vol 2, No. 2, (2006): 141-157.

Putri, Ni Wayan Krisnayanti Arwinda dan Ni Kt. Lely A. Merkusiwati. 2014. Pengaruh Mekanisme Corporate Governance, Likuiditas, Leverage, dan Ukuran Perusahaan pada Financial Distress, E-Jurnal Akuntansi Universitas Udayana 7.1 (2014):93-106. Universitas Udayana.

Sjahputra, Iman Tunggal dan Amin Widjaja Tunggal. 2002. Membangun Good Corporate Governance (GCG). Jakarta: Harvarindo.
Sugiyono. 2012. Metode Penelitian Bisnis. Bandung: Alfabeta.

Ujiyantho, Muh. Arief dan Bambang Agus Pramuka. 2007. Mekanisme Corporate Governance, Manajemen Laba dan Kinerja Keuangan. Simposisum Nasional Akuntansi X Unhas Makasar 26 - 28 Juli 2007. STIE Muhammadiyah dan Universitas Jendral Soedirman Purwokerto.

Wardhani, Ratna. 2006. Mekanisme Corporate Governance dalam Perusahaan yang Mengalami Permasalahan Keuangan (Financial Distress). Simposium Nasional Akuntansi 9 Padang. Universitas Indonesia.

Widyantini, Dian. 2009. Pengaruh Kepemilikan Institusional dan Leverage Terhadap Manajemen Laba. Tesis. Universitas Padjajaran. Tidak Dipublikasikan.

Widyasaputri, Erlindasari. 2012. Analisis Mekanisme Corporate Governance pada Perusahaan yang Mengalami Kondisi Financial Distress. Accounting Analysis Journal (AAJ) 1 (2) (2012). Universitas Negeri Semarang.

Widyati, Maria Fransisca. 2013. Pengaruh Dewan Direksi, Komisaris Independen, Komite Audit, Kepemilikan Manajerial, dan Kepemilikan Institusional Terhadap Kinerja Keuangan. Jurnal Ilmu Manajemen (JIM) Vol. 1, No. 1 (2013). 